\title{
Plant density and growth regulator applications in a tomato crop for industrial processing
}

\section{Densidad de plantas y aplicación del regulador de crecimiento al cultivo de tomate para procesamiento industrial}

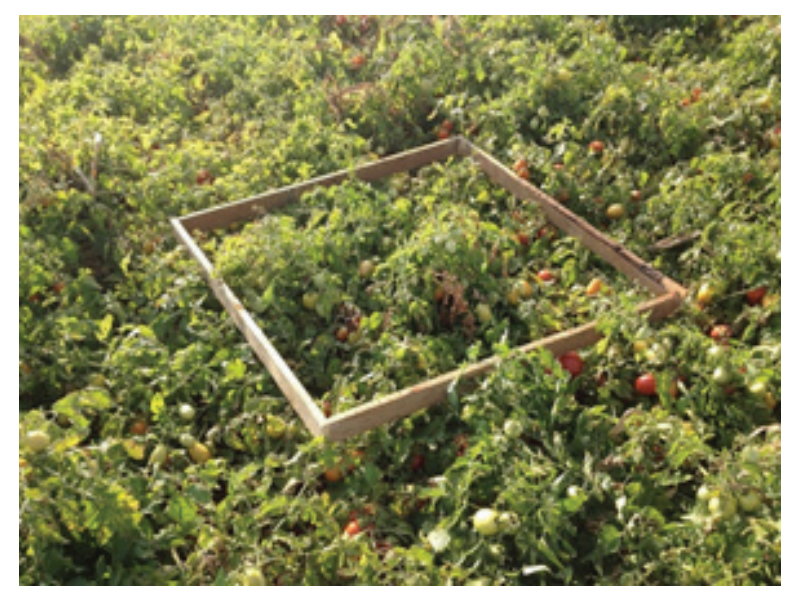

\author{
FÁBIO JOSÉ CARVALHO' \\ LORENA BRAZ CARNEIRO' \\ CLEITON GREDSON SABIN BENETT' 1,3 \\ KATIANE SANTIAGO SILVA BENETT ${ }^{1}$ \\ ANNE SILVA MARTINS ${ }^{1}$ \\ AMANDA TAVARES DA SILVA' \\ ALEXSANDER SELEGUINI ${ }^{2}$
}

\section{ABSTRACT}

Growth regulators are used in agriculture to reduce vegetative growth, promote flowering and fruiting processes, and regulate production alternations. In this study, the effects of the use of paclobutrazol (PBZ) and different plant arrangements on the development and productive yield tomatoes grown for industrial use were evaluated. This experiment was carried out in the experimental area of the Universidade Estadual de Goiás, in a randomized block design with a $2 \times 5$ factorial arrangement (presence of PBZ and absence of PBZ in seedlings $\times$ planting spacing), with four replications and ten plants per plot. The paclobutrazol (growth regulator) applications were carried out in seedlings 15 days after emergence by applying $3.5 \mathrm{~mL}$ of the solution per tray at a concentration of $42.5 \mathrm{mg} \mathrm{L}^{-1}$ using a commercial product containing $25 \%$ of the active ingredient for the solution. The spacings were $0.15,0.20,0.25,0.30$, and $0.35 \mathrm{~m}$ between plants and $1.4 \mathrm{~m}$ between rows, corresponding to populations of 47,$619 ; 35,714 ; 28,714 ; 23,809$ and 20,408 plants/ha, respectively. The initial growth and development of the seedlings, characteristics related to productivity, and the physical and chemical quality of fruits harvested in each experiment were evaluated. It was observed that the application of paclobutrazol influenced the phylotechnical characteristics and technological quality of tomato fruits grown for industrial processing. The planting spacings between 0.21 and $0.27 \mathrm{~m}$ had better crop development and productivity.

\footnotetext{
Additional keywords: Solanum lycopersicum L.; plant management; paclobutrazol; spacing.

State University of Goiás (Universidade Estadual de Goiás), Câmpus Ipameri, Ipameri (Brazil). ORCID Carvalho, FJ.: 0000-0002-7776-221X; ORCID Carneiro, L.B.: 0000-0002-0026-4992; Benett, C.G.S.: 0000-0001-7525-1857; ORCID Benett, K.S.S.: 0000-0002-4324-959X; ORCID Martins, A.S.: 0000-0002-0054-4521; ORCID Silva, A.T.: 0000-00029127-1265

2 Federal University of Triangulo Mineiro (Universidade Federal do Triangulo Mineiro), Iturama (Brazil). ORCID Seleguini, A.: 0000-0002-5762-9278

3 Corresponding author. cleiton.benett@gmail.com
} 


\section{RESUMEN}

Los reguladores del crecimiento se utilizan en la agricultura para reducir el crecimiento vegetativo, promover los procesos de floración y fructificación, además de regular la alternancia de producción. En este estudio, los efectos del uso de paclobutrazol (PBZ) y diferentes arreglos de plantas en el desarrollo y el rendimiento productivo de los tomates para la industria. El experimento se realizó en el área experimental de la Universidade Estadual de Goiás, en un diseño en bloques aleatorizados, en un arreglo factorial de $2 \times 5$ (presencia de PBZ y ausencia de PBZ en plántulas $\times$ distancia de siembra), con cuatro repeticiones y diez plantas por parcela. La aplicación de paclobutrazol (regulador del crecimiento) se realizó en plántulas 15 días después de la emergencia aplicando 3,5 $\mathrm{mL}$ de la solución por bandeja a la concentración de $42,5 \mathrm{mg} \mathrm{L}^{-1}$ utilizando el producto comercial que contiene el $25 \%$ del ingrediente activo para la solución. Los espacios disponibles fueron de 0,$15 ; 0,20 ; 0,25 ; 0,30$ y $0,35 \mathrm{~m}$ entre plantas y $1,4 \mathrm{~m}$ entre hileras, correspondientes a poblaciones de 47.619, 35.714, 28.714, 23.809 y 20.408 plantas/ha en cada espacio. Se evaluó el crecimiento inicial y el desarrollo de las plántulas, las características relacionadas con la productividad y la calidad física y química de los frutos cosechados en cada experimento. Se observó que la aplicación de paclobutrazol influyó en las características filotécnicas y la calidad tecnológica de los frutos de tomate para el procesamiento industrial. En cuanto a la densidad de siembra, el espacio de siembra entre 0,21 a 0,27 m mostró un mejor desarrollo del cultivo y productividad.

Palabras clave adicionales: Solanum lycopersicum L.; manejo de plantas; paclobutrazol; espaciamiento. Received for publication: 25-02-2019 Accepted for publication: 29-11-2019

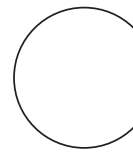

Tomato (Solanum lycopersicum L.) is an important source of vitamins, fiber and minerals (Naika et al., 2006). The fruits are a significant source of nutrients rich in phytochemicals, which are naturally produced by plants to protect them from viruses, bacteria and fungi. When ingested, they may have anticancer properties. Globally, the tomato crop is notable because of its economic, social importance, and versatility. It is consumed raw or processed as juice, sauce, pasta, and dehydrated (Fontes and Silva, 2005).

In Brazil, tomato crops occupy 65,200 ha. Production in Goiás totaled 1,290,134 $\mathrm{t}$ in 2019, with an area of 13,700 cultivated hectares, corresponding to $21 \%$ of the country's cultivated area (IBGE, 2020). The State of Goiás is the largest producer of industrial tomatoes in Brazil.

Industrial use requires special fruits produced in lowaltitude crops without complex cultural treatments, which reduces production costs. The fruits must have a high resistance to bulk transport, a uniform, intense red color, high soluble solids content, and high citric acid content. Tomato processing industries depend on the quality of the raw material to obtain final product quality (Schwarz et al., 2013).
Proper crop management is necessary for productivity gains and fruit quality with low production costs. Spacing is one of the main techniques in tomato cultivation. The effects of spacing can be observed on light exposure, increasing photosynthetic efficiency. Dense plantings provide a greater overlap and shading of leaves, and consequently a greater competition for light. This causes more energy expenditure (Mueller and Wamser, 2009). Spacing interferes with the crop cycle, making it difficult to control weeds and diseases and reducing fruit quality (Carvalho and Tessarioli Neto, 2005).

Plants produce plant hormones in certain parts and transport them to other parts where specific physiological responses are produced. Some hormones act in the same part where they are synthesized. Hormones are chemical messengers that are able to indicate the developmental status of cells, tissues, or organs. They are produced in various plant parts and are active at very small quantities (Taiz and Zeiger, 2013; Evert et al., 2017). The classes of plant hormones that receive the most attention are abscisic acid, auxins, cytokinins, ethylene, and gibberellins. The nomenclature "growth regulators" includes the natural or synthetic form of hormonal substances or substances 
that interfere with biosynthesis or hormonal action, which, when applied to plants, influence growth and development (Evert et al., 2017).

Growth regulators are used in agriculture to reduce vegetative growth, promote flowering and fruiting, and regulate the alternation of production (Silva and Fay, 2003). However, the degree of response of regulators varies according to species, cultivar, method of application, and concentration. These compounds include paclobutrazol, which generally provides increased productivity. However, some adverse effects, such as flowering inhibition and reduction of fruiting, have also been reported in the literature. Moreover, such effects vary according to factors such as mode, dose and timing of application, cultivar, climatic conditions, and crop culture (Silva and Faria Junior, 2011).

The use of growth regulators may be an option to obtain more compact plants, which allow for spatial arrangements that can improve yields and reduce the number of disbudding operations. Silva and Faria Junior (2011), working with growth regulators in a tomato crop, observed a decrease in the emergence of lateral buds, as well as a reduction in plant height.

The system of plant conduction may also interfere with results. Plant density, as well as apical pruning height in undetermined growth cultivars, significantly affects the yield and fruit quality of tomato crops. This study aimed to evaluate the effects of using a growth regulator and different spacings on tomato crops grown for industrial processing.

\section{MATERIAL AND METHODS}

\section{Characterization of the experimental area}

This project was developed at the experimental area of the State University of Goiás, campus Ipameri, located in the municipality of Ipameri, GO. The geographic coordinates are $17^{\circ} 43^{\prime} 04^{\prime \prime} \mathrm{S}$ and $48^{\circ} 08^{\prime} 43^{\prime \prime} \mathrm{W}$, and the altitude is $794 \mathrm{~m}$.

The climate of the region, according to the KöppenGeiger classification (Cardoso et al., 2014), is tropical climate (Aw), consisting of a dry season in winter. The soil of the experimental area is classified as dystrophic Red-Yellow Latosol (Santos et al., 2013). The chemical attributes and particle size analysis were determined before the installation of the experiment according to the methodology proposed by Ribeiro et al. (1999). The chemical attributes at the $0.0-0.20 \mathrm{~m}$ layer were $14 \mathrm{mg} \mathrm{dm}^{-3}$ of $\mathrm{P}$ (resin), $26 \mathrm{~g} \mathrm{~m}^{-3}$ of organic matter, pH $5.4\left(\mathrm{CaCl}_{2}\right), \mathrm{K}, \mathrm{Ca}, \mathrm{Mg}, \mathrm{H}+\mathrm{Al}=3.2,19.0$, 13.0 , and $29.0 \mathrm{mmol}_{\mathrm{c}} \mathrm{dm}^{-3}$, respectively, and $55 \%$ base saturation. The physical attributes were clay: $390 \mathrm{~g}$, silt: $97 \mathrm{~g}$, and sand: $513 \mathrm{~g}$.

\section{Characterization of the experiment}

This experiment used completely randomized blocks in a $2 \times 5$ factorial arrangement (presence of PBZ and absence of PBZ in seedlings $x$ planting spacing), with four replications and ten plants per plot. The hybrid was N901, with a cycle between 115 and $120 \mathrm{~d}$, used for industrial processing purposes. The color is intense red. It has high soluble solids contents, average mass of $80 \mathrm{~g}$, and resistance to various pests and diseases.

The evaluated spacings were $0.15,0.20,0.25,0.30$, and $0.35 \mathrm{~m}$ between plants and $1.4 \mathrm{~m}$ between rows, corresponding to populations of 47,619; 35,714; 28,714; 23,809 and 20,408 plants/ha, respectively. The plots consisted of four rows, $5 \mathrm{~m}$ long each. The two central lines were considered as the useful area, excluding $0.50 \mathrm{~m}$ from the ends of each line.

The production of seedlings was carried out in a commercial nursery with infrastructure, support, and specialized technicians. Polypropylene trays containing 450 cells and commercial organic-mineral substrate were used. The crop management and treatments were performed as recommended for the crop. The seedlings were transplanted $35 \mathrm{~d}$ after sowing.

The application of paclobutrazol (growth regulator) was carried out in seedlings $15 \mathrm{~d}$ after emergence by applying $3.5 \mathrm{~mL}$ of the solution per tray at a concentration of $42.5 \mathrm{mg} \mathrm{L}^{-1}$ using a commercial product containing $25 \%$ of the active ingredient for the solution.

\section{Phytotechnical evaluations}

The following were evaluated: Chlorophyll: indirect reading of chlorophyll content of sunflower leaves using the SPAD index obtained with a portable chlorophyll meter (clorofiLOG, modelo CFL 1030, Falker, Brazil); Final height: average of five plants per plot at 
harvest time using measuring tape; Final diameter: average of five plants per plot at the time of harvest using a caliper; Plant height growth rate: mean growth rates for plant height were obtained following Benincasa (1988); Stem diameter growth rate: mean growth rates for stem diameter were obtained following Benincasa (1988); Number of flowers: number of flowers of all useful plants of the plot in each treatment; Height of the first inflorescence: the height of the first inflorescence was measured using a graduated ruler; Fruit length: average length of fruits of five plants/plot was measured using a graduated ruler; Fruit diameter: average diameter of fruits of five plants/plot measured with a caliper; and Productivity: average productivity, in $\mathrm{kg} \mathrm{m}^{-2}$ per plot, for each treatment, weighed with the aid of digital scale.

\section{Technological evaluation of fruits}

The technological quality evaluations were carried out according to the Analytical Standards of the Adolfo Lutz Institute (1985). The following characteristics were evaluated:

Total titratable acidity (TTA): determined with titration using a $\mathrm{NaOH}$ solution $(0.05 \mathrm{~N})$ in $10 \mathrm{~mL}$ of pure juice obtained after liquefying at least three fully mature fruits; and Total soluble solids (TSS): determined by transferring a drop of the fruit juice to the prism of an refractometer (Insthutherm, model RTA-50) followed by a reading. The reading was corrected by the temperature conversion table and expressed in ${ }^{\circ}$ Brix (Chacón-Padilla and Monge-Pérez, 2017). TSS/ TTA ratio (Maturation index - MI) was obtained with the ratio between soluble solids content and titratable total acidity; $p H$ : was determined, directly in the ground pulp, using a digital benchtop pHmeter (Akso, model MP511); and Fruit texture: measured on the sides of the fruit using a penetrometer (Insthutherm, model PTR-100).

\section{Statistical analysis}

The data were subjected to analysis of variance ( $F$ test), and the means of qualitative (presence of PBZ and absence of PBZ) factor were compared with a Tukey test at $5 \%$ probability. For the quantitative factor (planting spacing), the means were submitted to polynomial regression fitting. Statistical analyses were performed using Statistical Analysis - SANEST (Zonta et al., 1987).

\section{RESULTS AND DISCUSSION}

The variables chlorophyll, final height, final diameter, height of the first inflorescence, number of flowers, growth rate, and stem growth rate had differences in the treatments (Tab. 1). The characteristics were statistically significant for one or more sources of variation, with a significant interaction for the absence or presence of growth regulator and planting spacing (Tab. 1).

The chlorophyll content of the tomato plants was affected significantly by the application of the growth regulator. The plants subjected to paclobutrazol had a higher chlorophyll content than the plants that did not receive the growth regulator (Tab. 1). These results corroborate those found by Ferreira et al. (2017), who also found higher contents of chlorophyll in plants subjected to applications of paclobutrazol 15 $\mathrm{d}$ after transplanting. Paclobutrazol increases photosynthetic rates and, consequently, the chlorophyll content of leaves (Berova and Zlatev, 2000). There was no statistical difference between the different spacings, and there was also no significant interaction between the plant spacings and use of growth regulator (Tab. 1).

For final height and final diameter, there was no significant effect from the use of the growth regulator and planting spacings. The means did not differ statistically. It was observed that there was no significant interaction between the use of the growth regulator and planting spacings. The values for final height and final diameter were between 96.42 and $102.06 \mathrm{~cm}$ and 16.06 and $16.30 \mathrm{~mm}$, respectively (Tab. 1). These results differ from those of Muller and Wamser (2009), who observed a linear decrease in plant height with increases in spacing between plants. Silva et al. (2008) reported that the use of paclobutrazol at a concentration of $150 \mathrm{ppm}$ reduced the size of the plants when analyzing the concentrations of $0 ; 50 ; 100$ and 150 ppm in a tomato crop. Ferreira et al. (2017) verified an increase in stem diameter using paclobutrazol at a concentration of $42.5 \mathrm{mg} \mathrm{L}^{-1}$ at 15 and $30 \mathrm{~d}$ after transplantation. Stems with a larger diameter favor the maintenance and sustentation of the plant and production during the crop cycle because of factors such as winds and rains.

For the analysis of the height of insertion of the first inflorescence, there was a significant effect from the use of growth regulator. The means differed statistically. The plants subjected to paclobutrazol had a higher insertion height of the first inflorescence (36.89 
Table 1. Chlorophyll (CHLOR), final height (FHE), final diameter (FD), height of the first inflorescence (HFI), number of flowers (NF), plant height growth rate (PHG), and stem diameter growth rate (SDGR) of tomato plants in the presence or absence of growth regulator and different plant spacings. Ipameri-GO.

\begin{tabular}{|c|c|c|c|c|c|c|c|}
\hline \multirow{2}{*}{ PBZ } & \multirow{2}{*}{$\begin{array}{l}\text { CHLOR } \\
\text { (Spad) }\end{array}$} & FHE & $\mathrm{FD}$ & $\mathrm{HFI}$ & \multirow[t]{2}{*}{ NF } & PHG & SDGR \\
\hline & & \multicolumn{3}{|c|}{$\mathrm{cm}$} & & \multicolumn{2}{|c|}{$\mathrm{cm} \mathrm{d}^{-1}$} \\
\hline Presence & $43.97 \mathrm{a}$ & $99.52 \mathrm{a}$ & $16.10 \mathrm{a}$ & 38.89 a & $95.17 \mathrm{a}$ & $1.37 \mathrm{a}$ & $0.203 b$ \\
\hline Absence & $42.33 b$ & 96.73 а & $16.22 \mathrm{a}$ & $35.19 b$ & $91.11 b$ & $1.31 \mathrm{a}$ & $0.211 \mathrm{a}$ \\
\hline F value & $7.06^{*}$ & $2.44^{\mathrm{NS}}$ & $0.577^{\mathrm{NS}}$ & $10.18^{*}$ & $6.08^{*}$ & $3.05^{\mathrm{NS}}$ & $9.44^{*}$ \\
\hline
\end{tabular}

Spacings $(\mathrm{m})$

\begin{tabular}{|l|c|c|c|c|c|c|c|}
\hline 0.15 & 42.75 & 102.06 & 16.30 & - & - & 1.40 & 0.210 \\
\hline 0.20 & 43.61 & 97.56 & 16.07 & - & - & 1.32 & 0.208 \\
\hline 0.25 & 42.33 & 97.22 & 16.06 & - & - & 1.31 & 0.208 \\
\hline 0.30 & 44.72 & 97.36 & 16.12 & - & - & 1.33 & 0.205 \\
\hline 0.35 & 42.35 & 96.42 & 16.25 & - & - & 1.33 & 0.205 \\
\hline F value & $2.18^{\text {NS }}$ & $1.25^{\mathrm{NS}}$ & $0.337^{\mathrm{NS}}$ & $15.25^{*}$ & $7.85^{*}$ & $0.92^{\mathrm{NS}}$ & $0.64^{\mathrm{NS}}$ \\
\hline Regression & - & - & - & $(2)$ & $(2)$ & - & - \\
\hline Interaction & - & - & - & $(1)$ & $(1)$ & - & - \\
\hline CV (\%) & 4.52 & 5.75 & 3.21 & 9.88 & 5.58 & 7.41 & 3.96 \\
\hline
\end{tabular}

Means with different lowercase letters in a column for each studied factor indicate a significant statistical differences according to the Tukey test $(P \leq 0.05)$. NS $=$ not significant; ${ }^{*}=$ significant at $5 \%$ probability. (1) Significant interaction for presence or absence of growth regulator and planting spacing and (2) Significant regression for effects of spacing.

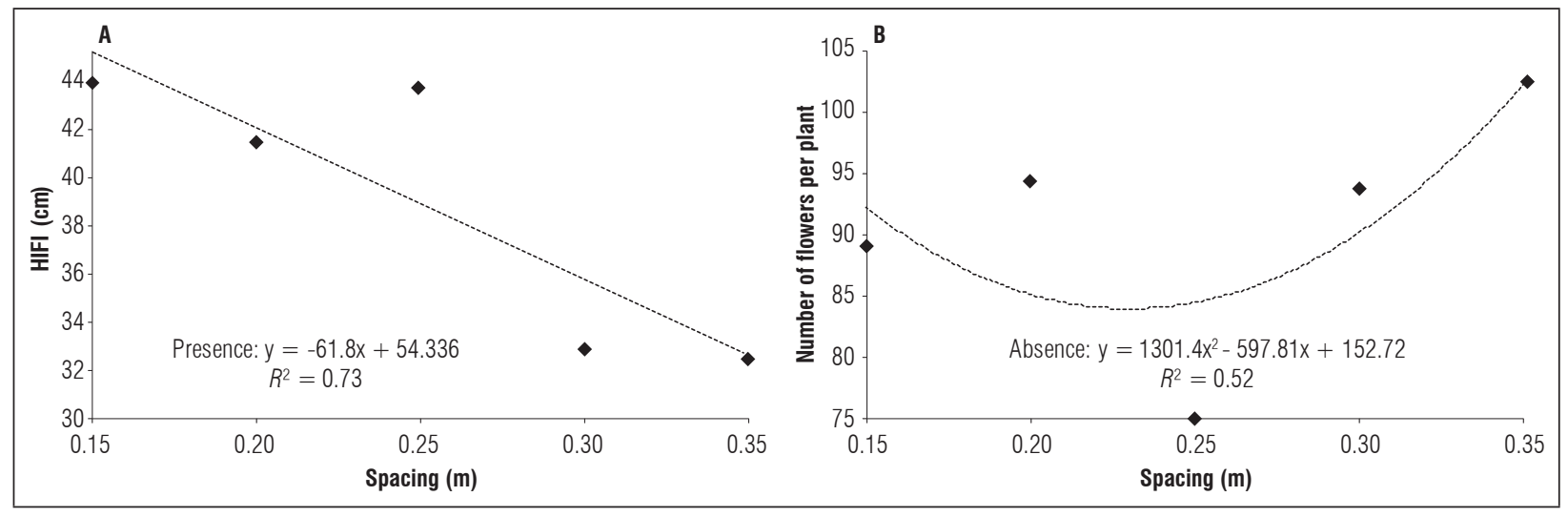

Figure 1. (A) Height of insertion of the first inflorescence (HIFI), and (B) number of flowers per plant of tomato plants in the presence or absence of growth regulator and planting spacing. Ipameri-GO.

$\mathrm{cm})$ than the plants that did not receive the growth regulator $(35.19 \mathrm{~cm})$ (Tab. 1). Seleguini et al. (2016) reported that there was a decrease in the height of the first inflorescence when using paclobutrazol at 50 and $100 \mathrm{mg} \mathrm{L}^{-1}$. When evaluating planting spacing and the absence or presence of paclobutrazol, there was a significant interaction only for the spacing in the presence of paclobutrazol. The values fitted a decreasing linear regression (Fig. 1A); as the plant spacing increased, the height of the first inflorescence decreased.
The number of flowers had statistically significant results for the use of growth regulator. The presence of paclobutrazol resulted in a greater number of flowers than the absence of paclobutrazol (Tab. 1). Thus, there was a significant interaction between planting spacing and growth regulator only in the absence of the growth regulator. The data fitted a quadratic regression with a minimum point of 0.22 m spacing (84.18 flowers) (Fig. 1B). 
The plant height growth rate had no significant effect between the use of growth regulator and planting spacing. These results differ from those found by Mueller and Wamser (2009), who verified a highly significant linear fit for plant height as a function of spacing between tomato plants. For the analysis of the use of growth regulator, only the stem diameter growth rate had significant results, indicating that the presence of paclobutrazol resulted in a lower stem growth rate $(0.203 \mathrm{~cm})$ when compared to values found in the absence thereof $(0.211 \mathrm{~cm})$ (Tab. 1). Figueiredo et al. (2015) observed different results when studying the behavior of undetermined tomato plants in the presence of a growth regulator. The authors reported significant effects of the regulator on stem diameter.

Tab. 2 shows the production components of the tomato crop as a function of the presence or absence of paclobutrazol and planting spacing. There was a significant interaction only for maturation index, total fruit acidity, and productivity (Tab. 2).

The variables fruit length and diameter did not present a statistical difference for the presence or absence of the growth regulator. These values differ from those found by Silva and Faria Junior (2011) who observed that an increase in the concentration of a growth regulator determined a linear increase in the percentage of small fruits. Seleguini et al. (2016) also noted that, regardless of the method of application of paclobutrazol, an increase in concentrations increased the production of small fruits. When evaluating planting spacings, there were significantly different results only between the different spacings. There was no significant interaction between plant spacing and use of growth regulator (Tab. 2). The different planting spacings in tomato crops are of great importance since they can interfere with the plant cycle, disease control, and quality and quantity of harvested fruits (Mueller and Wamser, 2009).

The maturation index presented significant results for the use of growth regulator. In the absence of paclobutrazol, there was a higher maturation index (7.71) than in the presence of the growth regulator (7.08), with statistically different means (Tab. 2). These values differ from the results found by Seleguini et al. (2011). In their study, the TSS/TTA ratio was not influenced by PBZ concentrations. By evaluating planting spacing, there was a significant interaction between spacing and use of growth regulator. In the presence of paclobutrazol, the data fitted a quadratic regression with a minimum point of $0.22 \mathrm{~m}$ spacing

Table 2. Fruit length (FL), fruit diameter (FD) maturation index (SST/TTA), fruit texture (FT), fruit pH (pH), total soluble solids (TSS), total fruit acidity (TTA), and productivity (PROD) of tomato plants in the presence or absence of growth regulator and planting spacings. Ipameri, GO.

\begin{tabular}{|c|c|c|c|c|c|c|c|c|}
\hline \multirow{2}{*}{ PBZ } & $\mathrm{FL}$ & FD & TSS/TTA & $\mathrm{FT}$ & $\mathrm{pH}$ & TSS & TTA & PROD \\
\hline & \multicolumn{2}{|c|}{$\mathrm{cm}$} & & $\mathrm{lb} \mathrm{pol}^{-2}$ & & ${ }^{\circ}$ Brix & $\%$ & $\mathrm{tha}^{-1}$ \\
\hline Presence & $5.54 \mathrm{a}$ & $4.50 \mathrm{a}$ & $7.08 b$ & $10.84 \mathrm{a}$ & $4.50 \mathrm{a}$ & $4.42 b$ & $0.64 \mathrm{a}$ & $92 \mathrm{a}$ \\
\hline Absence & $5.41 \mathrm{a}$ & $4.39 \mathrm{a}$ & $7.71 \mathrm{a}$ & $8.59 b$ & $4.45 b$ & $4.60 \mathrm{a}$ & $0.60 \mathrm{~b}$ & $67 b$ \\
\hline F value & $2.05^{\mathrm{NS}}$ & $2.33^{\mathrm{NS}}$ & $11.72^{*}$ & $18.72^{*}$ & $4.68^{*}$ & $8.69 *$ & $4.69 *$ & $84.82^{*}$ \\
\hline \multicolumn{9}{|l|}{ Spacings (m) } \\
\hline 0.15 & 5.57 & 4.47 & - & 9.42 & 4.47 & 4.48 & - & - \\
\hline 0.20 & 5.72 & 4.57 & - & 10.27 & 4.40 & 4.63 & - & - \\
\hline 0.25 & 5.10 & 4.22 & - & 9.28 & 4.46 & 4.38 & - & - \\
\hline 0.30 & 5.47 & 4.53 & - & 9.77 & 4.57 & 4.56 & - & - \\
\hline 0.35 & 5.51 & 4.43 & - & 9.81 & 4.47 & 4.48 & - & - \\
\hline F value & $4.84^{*}$ & $2.88^{*}$ & $9.32^{*}$ & $3.62^{*}$ & $7.28^{*}$ & $1.77^{\mathrm{NS}}$ & $8.18^{*}$ & $10.17^{*}$ \\
\hline Regression & - & - & (2) & - & - & - & (2) & (2) \\
\hline Interaction & - & - & (1) & - & - & - & (1) & (1) \\
\hline CV (\%) & 5.43 & 5.11 & 7.92 & 5.41 & 1.46 & 4.39 & 9.41 & 10.69 \\
\hline
\end{tabular}

Means with different lowercase letters in a column for each studied factor indicate a significant statistical differences according to the Tukey test $(P \leq 0.05)$. Ns $=$ not significant; ${ }^{*}=$ significant at 5\% probability. (1) Significant interaction for presence or absence of growth regulator and planting spacing, and (2) $=$ Significant regression for effects of spacing. 
(6.46) (Fig. 2A). In the absence of paclobutrazol, the data also fitted a quadratic regression with a minimum point of $0.26 \mathrm{~m}$ spacing (6.51) (Fig. 2B). These values differ from the results found by Ferreira et al. (2017), who did not report influence from different planting spacings on the variable maturation index.

The variables fruit texture and fruit $\mathrm{pH}$ presented significant results for the use of the growth regulator; the best results were found with the presence of paclobutrazol (10.84 and 4.50) for fruit texture and $\mathrm{pH}$ (respectively) (Tab. 2). However, for planting spacing, there was no significant interaction between planting spacing and the presence or absence of PBZ in the seedlings (Tab. 2). The $\mathrm{pH}$ value is very important when the fruit is destined for processing, with a $\mathrm{pH}$ below 4.5 being desirable for preventing the proliferation of microorganisms (Monteiro et al. 2008); results within this standard were observed in this study (Tab. 2).

The fruit TSS had significant results only for the use of the growth regulator (Tab. 2). In the absence of paclobutrazol, the fruits had a higher TSS (4.60), differing statistically from the values found in the presence of paclobutrazol (4.42). There was a significant interaction between planting spacing and use of the growth regulator (Tab. 2).

The total fruit acidity also presented significant results for the use of the growth regulator. The total fruit acidity was higher in the presence of paclobutrazol (0.64), differing statistically from the results found in the absence of paclobutrazol (0.60) (Tab. 2 ). However, when evaluating the planting spacings, there was a significant interaction between the spacings and the use of the growth regulator for the total acidity (Tab. 2). The data fitted a quadratic regression for the presence and absence of paclobutrazol, with maximum points of $0.21 \mathrm{~m}$ spacing $(0.69)$ and $0.27 \mathrm{~m}$ spacing (0.67), respectively (Fig. 2B).

For productivity, there were significant results. The averages differed statistically for the use of the growth regulator. The crop productivity was higher with the presence of paclobutrazol (92 t) and lower with the absence of paclobutrazol (67 t) (Tab. 2). There was a significant interaction between planting spacing and use of growth regulator. The values in the presence of paclobutrazol fitted a linear regression. The values were between 124 and $58 \mathrm{t}$. In the absence of paclobutrazol, the values fitted a quadratic regression, with a maximum point of $0.18 \mathrm{~m}$ planting

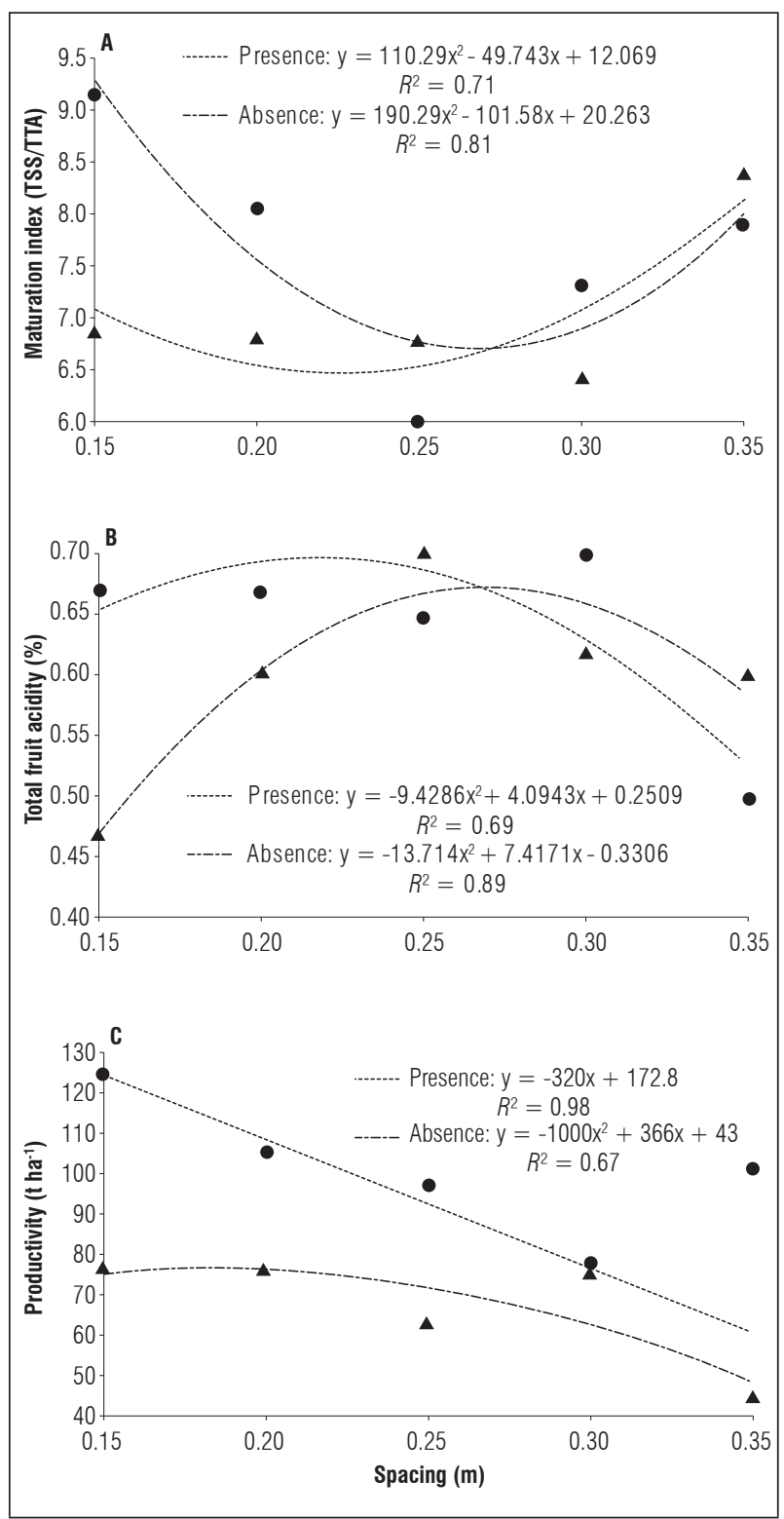

Figure 2. (A) Maturation index, (B) total titratable acidity, and (C) productivity of tomato plants as a function of the presence or absence of growth regulator and planting spacing. Ipameri, GO.

spacing (76.48 tha ${ }^{-1}$ ) (Fig. 2C), indicating that, in the absence of the regulators, the increase in the spacing resulted in a decrease in productivity. Hachmann et al. (2014) obtained a higher productivity when plants were planted at a smaller spacing. After comparing the crop conduction of super-dense tomatoes with the traditional density of plants in the 2008/2009 harvest, Wamser et al. (2012) reported a higher productivity in the super-dense tomatoes. Benetti et al. (2018) observed that tomato productivity was 
significantly modified by different spacings, with the highest productivity obtained when tomato plants were conducted at a $50 \mathrm{~cm}$ spacing between plants. Thus, a greater number of plants per area offsets competition between plants in dense planting.

\section{CONCLUSIONS}

It was observed that the application of paclobutrazol influenced the phylotechnical characteristics and technological quality of tomato fruits grown for industrial processing. For the planting density, the planting spacing between 0.21 and $0.27 \mathrm{~m}$ had better crop development and productivity.

\section{ACKNOWLEDGMENTS}

The authors thank the State University of Goiás. Campus Ipameri (State University of Goiás, Campus Ipameri) for supporting the installation and maintenance of this project and the Phytotechnics Study and Research Group (GEPFi), Public call no. 02/2012 - Scientific and technological development - DCR FAPEG/CNPq. This study was financed in part by the Coordenação de Aperfeiçoamento de Pessoal de Nível Superior - Brasil (CAPES) - Finance Code 001 (Convênio nº 817164/2015 CAPES/PROAP).

Conflict of interests: the manuscript was prepared and reviewed with the participation of the authors who declare that there is no conflict of interest that puts the validity of the results presented here at risk.

\section{BIBLIOGRAPHIC REFERENCES}

Adolfo Lutz Institute. 1985. Normas analíticas do Instituto Adolfo Lutz. I - Métodos químicos e físicos para análise de alimentos. $3^{\text {rd }}$ ed. Instituto Adolfo Lutz, Sao Paulo, Brazil.

Benetti, R., K.S.S. Benett, N. Arruda, C.G.S. Benett, and A. Seleguini. 2018. Densidade de plantio e substâncias húmicas no cultivo do tomateiro (Solanum lycopersicum L.). Rev. Agric. Neotrop. 5(1), 75-81. Doi: 10.32404/ rean.v5i1.2136

Benincasa, M.M.P. 1988. Análise de crescimento de plantas: noções básicas. FUNEP, Jaboticabal, Brazil.

Berova, M. and Z. Zlatev. 2000. Physiological response and yield of paclobutrazol treated tomato plants (Lycopersicon esculentum Mill.). Plant Growth Regul. 30(2). 117123. Doi: 10.1023/A:1006300326975
Cardoso, M.R.D., F.F.N. Marcuzzo, and J.R. Barros. 2014. Classificação climática de Köppen-Geiger para o Estado de Goiás e o Distrito Federal. Acta Geográf. 8(16), 40-55. Doi: 10.5654/acta.v8i16.1384

Carvalho, L.A. and J. Tessarioli Neto. 2005. Produtividade de tomate em ambiente protegido, em função do espaçamento e número de ramos por planta. Hort. Bras. 23(4), 986-989. Doi: 10.1590/S0102-05362005000400025

Chacón-Padilla, K. and J. Monge-Pérez, 2017. Evaluación de rendimiento y calidad de seis genotipos de pepino de frutos largos (Cucumis sativus L.) cultivados bajo invernadero en Costa Rica, durante la época seca. Rev. Colomb. Cienc. Hortic. 10(2), 323-332. Doi: 10.17584/ rcch.2016v10i2.5069

Evert, R.F., S.E. Eichhorn, and C.M. Vieira. 2017. Biologia vegetal. $8^{\text {th }}$ ed. Guanabara Koogan, Rio de Janeiro, Brazil.

Ferreira, N.C., E.P. Vendruscolo, A. Seleguini, W.D.S. Dourado, C.S.G. Benett, and A.D.R. Nascimento. 2017. Crescimento, produção e qualidade de frutos de tomateiro em cultivo adensado com uso de paclobutrazol. Rev. Colomb. Cienc. Hortic. 11(1), 72-79. Doi: 10.17584/ rcch.2017v11i1.5690

Figueiredo, A.S.T., L. Meert, J.T. de Paula, J.T.V. de Resende, J.D. Rodrigues, and E.O. Ono. 2015. Comportamento de plantas de tomateiro indeterminado na presença de regulador de crescimento. Campo Digital 10(1), 31-40.

Fontes, P.C.R. and D.J.H. Silva. 2005. Cultura do tomate. pp. 457-475. In: Rezende, P.C. (ed.). Olericultura: teoria e prática. Universidade Federal de Viçosa, Viçosa, Brazil.

Hachmann, T.L., M.M. Echer, G.M. Dalastra, E.S. Vasconcelos, and V.F. Guimarães. 2014. Cultivo do tomateiro sob diferentes espaçamentos entre plantas e diferentes níveis de desfolha das folhas basais. Bragantia 73(4), 399-406. Doi: 10.1590/1678-4499.0163

IBGE, Instituto Brasileiro de Geografia e Estatística. 2020. Levantamento sistemático da produção agrícola. In: https://sidra.ibge.gov.br/tabela/1618; consulted: January, 2020.

Monteiro, C.S., M.E. Balbi, O.G. Miguel, P.T.P.S. Penteado, and S.M.C. Haracemiv. 2008. Qualidade nutricional e antioxidante do tomate "tipo italiano". Alim. Nutr. 19(1), 25-31.

Mueller, S. and A.F. Wamser. 2009. Combinação da altura de desponte e do espaçamento entre plantas de tomate. Hort. Bras. 27(1), 064-069. Doi: 10.1590/ S0102-05362009000100013

Naika, S., J.V.L. Jeude, M. Goffau, M. Hilmi, and B.V. Dam. 2006. A Cultura do tomate. Fundação Agromisa e CTA, Wageningen, The Netherlands.

Ribeiro, A.C., P.T.G. Guimarães, and V.H.V. Alvares. 1999. Recomendação para o uso de corretivos e fertilizantes em Minas Gerais: $5^{\mathrm{a}}$ aproximação. $5^{\text {th }}$ ed. Comissão de 
Fertilidade do Solo do Estado de Minas Gerais, Viçosa, Brazil.

Santos, H.G., P.K.T. Jacomine, L.H.C. Anjos, V.A. Oliveira, J.F. Lumbreras, M.R. Coelho, J.A. Almeida, T.J.F. Cunha, and J.B. Oliveira. 2013. Sistema brasileiro de classificação de solos. $3^{\text {rd }}$ ed. Embrapa, Brasilia.

Schwarz, K.J.T.V., A.P. Resende, J.T. Preczenhak, E. Paula, and D.M. Dias. 2013. Desempenho agronômico e qualidade físico-química de híbridos de tomateiro em cultivo rasteiro. Hort. Bras. 31(3), 410-418. Doi: 10.1590/ S0102-05362013000300011

Seleguini, A., M.J.A. Faria Júnior, S. Seno, J.I. Santos, K.S. Silva, and O.L. Lemos. 2011. Vida útil e qualidade de frutos de tomateiros tratados com paclobutrazol. Rev. Ceres 58(4), 470-475. Doi: 10.1590/ S0034-737X2011000400010

Seleguini, A., E.P. Vendruscolo, L.F.C. Campos, and M.J.A. Faria Júnior. 2016. Efeito do paclobutrazol sobre o crescimento de plantas e produção de tomate (Solanum lycopersicum L.) em ambiente protegido. Sci. Agropecu. 7(4), 391-399. Doi: 10.17268/sci.agropecu.2016.04.04
Silva, C.M.M.S. and E.F. Fay. 2003. Impacto ambiental do regulador de crescimento vegetal paclobutrazol. Embrapa Meio Ambiente, Jaguariúna, Brazil.

Silva, K.S., C.G.S. Benett, A. Seleguini, R.C. Lima, M.J.A. Faria Junior, and S. Seno. 2008. Uso de paclobutrazol no cultivo de tomateiro em campo e ambiente protegido: I. Crescimento de plantas e emissão de brotos laterais. Hort. Bras. 26(2), 256-260.

Silva, K.S. and M.J.A. Faria Junior. 2011. Uso de paclobutrazol como estratégia para redução do porte e da brotação lateral de plantas de tomateiro. Ciênc. Agrotec. 35(3), 539-546. Doi: 10.1590/S1413-70542011005000004

Taiz, L. and E. Zeiger. 2013. Fisiologia vegetal. $5^{\text {th }}$ ed. Artmed, Porto Alegre, Brazil.

Wamser, A.F., S. Mueller, A. Suzuki, W.F. Becker, and J.P. Santos. 2012. Produtividade de híbridos de tomate submetidos ao cultivo superadensado. Hort. Bras. 30(1), 168-174. Doi: 10.1590/S0102-05362012000100028

Zonta, E.P., A.A. Machado, and P. Silveira Junior. 1987. Sistema de análise estatística para microcomputadores: manual de utilização. $2^{\text {nd }}$ ed. UFPel, Pelotas, Brazil. 